\title{
Performance of cowpea as influenced by native strain of rhizobia, lime and phosphorus in Samaru, Nigeria
}

\author{
S. K. Bello ${ }^{1}$ A. A. Yusuf $^{1} \cdot$ M. Cargele $^{2}$
}

Received: 1 June 2017 / Accepted: 1 September 2017 /Published online: 14 September 2017

(C) The Author(s) 2017. This article is an open access publication

\begin{abstract}
The complimentary effects of a native rhizobia strain (SAMFIX 286), lime and single superphosphate (SSP) as components of ISFM were evaluated on the biomass, nodulation and $\mathrm{N}_{2}$ fixation of cowpea (Vigna unguiculata $\mathrm{L}$.). Lime was applied at the rate of $250 \mathrm{~kg}\left(\mathrm{Ca}(\mathrm{OH})_{2}\right) \mathrm{ha}^{-1}$, while SSP was applied at $30 \mathrm{~kg} \mathrm{P} \mathrm{ha}^{-1}$. The trial was carried out in a screen house with the treatments arranged in randomized complete block design. Results obtained show that the performance of SAMFIX 286 inoculated plants did not significantly $(p<0.05)$ differ from that of the un-inoculated treatment. Application of lime significantly increased root dry weight, shoot dry weight, nodule number and dry weight by $42.5 \%, 35.3 \%, 65.6 \%$ and $50 \%$, respectively. Nodulation was significantly $(p<0.05)$ increased by SSP. The complimentary effect of lime with SSP significantly increased total shoot N concentration. Similarly, combined inoculation of SAMFIX 286 with lime and SSP increased $\mathrm{N}$ concentration by $31.9 \%$ and $\mathrm{N}$ derived from atmosphere (Ndfa) by $16.3 \%$ compared to the un-inoculated treatment. Inoculation of SAMFIX 286 with SSP was also effective on Ndfa by cowpea. It was concluded that lime and SSP were good combination with native rhizobia strain in improving cowpea nodulation and biological $\mathrm{N}_{2}$ fixation.
\end{abstract}

Presented at the 17th African Association of Biological Nitrogen Fixation (AABNF) Biennial Conference, Gaborone, Botswana, 17-21 October 2016.

S. K. Bello

bellosuleimank@gmail.com; skbello@abu.edu.ng

1 Department of Soil Science, Faculty of Agriculture/Institute for Agricultural Research, Ahmadu Bello University, P.M.B. 1044, Zaria, Kaduna State, Nigeria

2 International Institute of Tropical Agriculture, P.O. Box 30772-00100, Nairobi, Kenya
Keywords Biological nitrogen fixation · Integrated soil fertility management $\cdot$ Bradyrhizobium strain $\cdot$ Lime $\cdot$ Single superphosphate $\cdot$ Cowpea

\section{Introduction}

Low soil fertility is increasingly recognized as a fundamental biophysical cause for declining food security among smallfarm households in sub-Saharan Africa (Sanchez et al. 1997). Poor soil fertility continues to represent huge obstacles to securing needed harvest (Sanginga and Woomer 2010). Reports also indicate that poor legume productivity on most small holder farms in sub-Saharan Africa is due to declining soil fertility and as a result of poor soil management practices (Chianu et al. 2011; Balume 2013). Thus, the integrated soil fertility management (ISFM) technique has been advocated as an approach to sustainably improve the soil fertility status of African soils. The set of soil fertility management practices included in ISFM are the use of fertilizer, organic inputs, and improved germplasm combined with the knowledge on how to adapt these practices to local conditions, aiming at maximizing agronomic use efficiency of the applied nutrients and improving crop productivity (Vanlauwe et al. 2010). While each component of ISFM can have a positive contribution to soil fertility and crop productivity, the aim of ISFM is to integrate multiple technologies in order to exploit complementarities among different protocols (Marenya and Barrett 2007).

Given the poor natural endowments of African soils, aggravated by poor management and sometimes nonappropriated soil practices, there is broad consensus that substantial increases in inorganic fertilizer use are necessary to restore and maintain the fertility of such soils to enhance their productivity (Minot and Benson 2009). Therefore, the use of inorganic fertilizers is part of the ISFM approach. The 
beneficial effects of combined organic and inorganic sources on soil fertility, crop yields, and maintenance of soil organic matter have repeatedly been shown in field trials (Chand et al. 2006; Nandwa 2003; Vanlauwe et al. 2002; Zerihun et al. 2013). Farmers use strategies such as application of organic and inorganic fertilizers, phosphate rocks, Rhizobium inoculants (Mungai and Karubiu 2011) and lime to address challenges of low soil fertility. The application of phosphorus (P) results in increased benefits in terms of yield and quality as it plays key roles in cellular energy transfer, respiration, photosynthesis and biological nitrogen fixation (Blackshaw and Brandt 2009; Mapfumo 2011; Jansa et al. 2011). Raising soil $\mathrm{pH}$ with lime results in greater activities of soil bacteria (Sanginga and Woomer 2010) which in turn increases soil organic matter decomposition, mineralization and nutrient cycling (Woomer et al. 1994) and also supplies $\mathrm{Ca}^{2+}$ for plant growth (White and Broadley 2003). However, organic and chemical fertilizers are not available to low-input African farmers majorly due to their associated high cost as generally those farmers are resource-poor. Thus, the introduction of selected beneficial microbes via biofertilizers could be considered as a practical, low cost strategy to improve crop yields in Africa.

Cowpea (Vigna unguiculata L. Walp) is one of the most important edible grain legumes in Africa contributing to food security and maintenance of environment for millions of small-scale farmers in sub-Saharan Africa (SSA) (Tarawali et al. 2002). Nigeria is the world's largest producer of cowpea that supplies up to $40 \%$ of the daily protein intake of its constantly increasing population (Miko and Mohammed 2007). According to FAO data (2001-2010), Nigeria produces an average of $2.58 \pm 0.31$ million metric tonnes (AATF 2012). Thus, innovative research must be conducted to enhance the sustainability and improvement of cowpea production in Nigeria. Apart from the socio-economic value of cowpea, it has the ability to establish symbiosis with soil rhizobia to fix atmospheric $\mathrm{N}_{2}$ for growth, with the surplus $\mathrm{N}_{2}$ fixed benefiting succeeding crops (AATF 2012). The total of $\mathrm{N}_{2}$ fixed by grain legumes in SSA range from 11 to $201 \mathrm{~kg} \mathrm{~N} \mathrm{ha}^{-1}$ for sole cropped cowpea (Giller et al. 1997), while in Nigeria the cowpea planted in the Northern Guinea savanna zone was estimated to fix 16-34 $\mathrm{kg} \mathrm{N} \mathrm{ha}^{-1}$ (Yusuf et al. 2007). Therefore, the biological nitrogen fixation (BNF) can reduce the need for $\mathrm{N}$ fertilizers, resulting in an economy estimated in US\$ 3 billion per crop season (Mwangi 1994; Vinuesa et al. 2003; Shamseldin and Werner 2004; Nicolás et al. 2006; Shamseldin 2007). Inoculation with an effective and persistent rhizobial strain has numerous advantages, which include a marked reduction in the applied $\mathrm{N}$ fertilizer and the higher pod yield due to increased nodulation (Sanginga et al. 1994). Studies have shown that legumes dependent on symbiotic N fixation have high P requirement (IPNI 1999; Schulze et al. 2006; Raven 2012), which would be critical in acidic soil due to higher $\mathrm{P}$ fixation. Liming would enhance $\mathrm{P}$ availability to crops, and consequently improve the efficiency of legumesrhizobia symbiosis in acidic soils. Based on this information, the main objective of this research was to test the effect of a native rhizobia strain, lime and phosphorus as ISFM components on cowpea growth in Samaru, Nigeria.

\section{Materials and methods}

\subsection{Experimental site, soil sample collection and preparation}

The trial was carried out in 2014 in a screen house at the Institute for Agricultural Research (IAR), Ahmadu Bello University (ABU), Samaru, Zaria located in the northern Guinea savanna (NGS) zone of Nigeria within longitudes $007^{0} 37.968^{\prime} \mathrm{E}$ and latitudes $11^{\circ} 09.974^{\prime} \mathrm{N}$, and an altitude of $698 \mathrm{~m}$ above sea level. Soil samples for laboratory analysis and screen house experiment were collected from the research farm (Field S13) of IAR. Field S13 is located on longitudes $007^{\circ} 36.865^{\prime} \mathrm{E}$ and latitudes $11^{\circ} 11.018^{\prime} \mathrm{N}$ with an altitude of $701 \mathrm{~m}$ above sea level. On the basis of cropping history, it has been put into continuous cultivation with different mixtures of cowpea, groundnut and soybean over 20 years.

Soil samples were randomly collected using an auger at every $10 \mathrm{~m}^{2}$ within an area of $100 \mathrm{~m}^{2}$. The sampling depths were $0-5 \mathrm{~cm}$ for microbial analysis, $0-20 \mathrm{~cm}$ for analysis of soil physical and chemical properties and the screen house experiment. The soil samples were bulked, air dried and sieved through $2 \mathrm{~mm}$ mesh for routine soil analysis and $4 \mathrm{~mm}$ mesh for screen house experiments. Organic carbon $(\mathrm{C})$ and total nitrogen $(\mathrm{N})$ were determined from soils sieved through $0.5 \mathrm{~mm}$ mesh. For sowing in the screen house, experimental pots $(12 \mathrm{~cm}$ in diameter) were filled with $10 \mathrm{~kg}$ of soil each.

\subsection{Application rates of the treatments and experimental layout}

The rates of lime,, $\mathrm{P}$ and $\mathrm{K}$ used in this study were within the range ( 250 to $500 \mathrm{~kg} \mathrm{ha}^{-1}$ for lime, 24 to $30 \mathrm{~kg} \mathrm{P} \mathrm{ha}^{-1}$, and 17 to $25 \mathrm{~kg} \mathrm{~K} \mathrm{ha}^{-1}$ ) of current agronomic practices in the region. Briefly, lime $\left(\mathrm{Ca}(\mathrm{OH})_{2}\right)$ was applied at $250 \mathrm{~kg} \mathrm{ha}^{-1}$ prior to sowing, single superphosphate (SSP) at $30 \mathrm{~kg} \mathrm{P} \mathrm{ha}^{-1}$, and muriate of potash (MOP) at $17 \mathrm{~kg} \mathrm{~K} \mathrm{ha}^{-1}$ at sowing. Factorial combination was used to allot each treatment and treatment combinations to their respective pots (Table 1) except muriate of potash, which was applied to all the pots as a blanket treatment. The test crop was Vigna unguiculata, variety IT-89KD-288. Soil inoculation of the isolated native rhizobia strain, SAMFIX 286, was done by injecting $5 \mathrm{ml}$ of the inoculant around the seedlings rhizosphere at 2 weeks after 
Table 1 Treatments and treatment structure

\begin{tabular}{ll}
\hline Treatments & Cowpea \\
\hline Inoculants & Un-inoculated \\
& SAMFIX 286 \\
Lime & Lime \\
Single Superphosphate (SSP) & SSP \\
INTERACTIONS & \\
& Inoculant X Lime \\
& Inoculant X SSP \\
& Lime X SSP \\
& Inoculant X Lime X SSP \\
\hline
\end{tabular}

sowing. The experimental pots were arranged in randomized complete block design with three replicates.

\subsection{Laboratory analysis}

\subsubsection{Soil chemical analysis}

Soil chemical analysis was done using standard recommended methods. Soil $\mathrm{pH}$ was determined at soil:water ratio of 1:2.5 (IITA 1982), particle size distribution was determined using hydrometer method (Gee and Bauder 1986), total $\mathrm{N}$ was determined using the macro Kjeldahl digestion method as described by Bremner and Mulvaney (1982), organic carbon was determined using dichromate oxidation method (Nelson and Sommers 1982). The total $P$ was determined using the wet oxidation method (ISRIC 1995) and the available P was extracted using Bray 1 (Bray and Kurtz 1945). The available $\mathrm{P}$ was finally estimated colorimetrically as described by Murphy and Riley (1962). Exchangeable bases were extracted using $1 \mathrm{~N}$ ammonium acetate and flame photometer reading was used to determine $\mathrm{K}$, while atomic absorption spectrophotometer (AAS) was used to determine $\mathrm{Ca}$ and $\mathrm{Mg}$. Exchangeable acidity was determined by titration method after extraction with $1 \mathrm{~N} \mathrm{KCl}$ (Anderson and Ingram 1993). Effective cation exchange capacity (ECEC) was determined by summation of exchangeable bases and acids.

\subsubsection{Treatment application and sowing}

The application of lime was done prior to sowing. Seeds were surface sterilized prior to sowing by using $70 \%$ ethanol $\left(\mathrm{C}_{2} \mathrm{H}_{5} \mathrm{OH}\right)$ for $10 \mathrm{~s}$, and $5 \%$ sodium hypochlorite $(\mathrm{NaOCl})$ for $3 \mathrm{~min}$ and rinsed six times with sterile water. Distilled water was used to irrigate the pots throughout the experiment in order to reduce the nutrient load especially nitrates that may be supplied to the plants if tap water is used. The tap water could also be a source of high chlorine which is toxic to rhizobia. Five seeds per pot were sowed and later thinned to two seedlings per pot at 2 weeks after sowing.

\subsubsection{Most probable number of native Rhizobia strains}

The most probable number (MPN) was used to estimate the number of viable native rhizobia present in the experimental soil using the plant infection method. Hydroponic culture using Broughton and Dilworth N-free plant nutrient solution (Woomer et al. 1988) inoculated with serial dilution of the soil was used as a medium to grow cowpea for six weeks in growth pouches. The presence of nodules on cowpea at the end of the sixth week was used as an indication for the presence of rhizobia in the soil. The soil serial dilution was a fivefold six step dilution $\left(5^{-1}\right.$ to $5^{-6}$ ) (Woomer et al. 2010) as shown in in Eq. 1.

Five-fold dilution

$=\frac{\text { Volume of Sample }(1 \mathrm{ml})}{\text { Volume of Sample }(1 \mathrm{ml})+\text { Volume of Diluent }(4 \mathrm{ml})}$

Final rhizobia counts were determined using the MPN table with confidence intervals of $p<0.05$ (Somasegaran and Hoben 1985).

\subsubsection{Colony forming units of the native rhizobia strain}

The MPN, expressed as colony forming units (CFU) per ml of inoculants was determined using the drop plate method as described by Woomer et al. (2010). Ten-fold, eight-step $\left(10^{-1}\right.$ $10^{-8}$ ) serial dilutions of the native Rhizobium inoculant was made by adding $1 \mathrm{ml}$ of yeast mannitol broth (YMB) culture to $9 \mathrm{ml}$ of sterile water. $0.01 \mathrm{ml}$ of the aliquots were transferred aseptically to dried yeast mannitol agar (YMA) plate having eight equal sectors being radially marked off on the outside bottom of the Petri dishes. The aliquots were allowed to dry by absorption into the agar. Thereafter, the plates were inverted and incubated for five days at $26-28^{\circ} \mathrm{C}$ to allow for the growth of rhizobium colonies. At the end of the procedures, the CFU count was calculated as shown in Eq. 2.

MPN $\left(\right.$ CFU $\left.m l^{-1}\right)=\#$ Colonies $\times$ Dilution Factor

$$
\times \text { Inoculum Volume }
$$

where MPN, CFU, and '\# colonies' stand for most probable number, colony forming units, and number of colonies, respectively.

\subsubsection{Plant sampling and tissue analysis}

Plants (all plants per pot) were harvested at 8 weeks after sowing, early period of the reproductive growth stage, for tissue analysis. Total $\mathrm{N}$ was determined by using the macro 
Kjeldahl digestion method as described by Bremner and Mulvaney (1982).

\subsubsection{Biological nitrogen fixation using the $N$ difference method}

Alongside the leguminous crop, maize was planted as a non$\mathrm{N}_{2}$-fixing reference crop in order to estimate the amount of $\mathrm{N}$ fixed and percent $\mathrm{N}$ derived from BNF. Both the leguminous and maize crops were planted with same soil and under identical conditions in the screen house. After harvesting, the shoots were oven dried and analysed for total $\mathrm{N}$ to quantify $\mathrm{N}$ fixation. The amount of $\mathrm{N}$ fixed and percent $\mathrm{N}$ derived from BNF are estimated with the Eqs. 3 to 5 described by Mary et al. (1995).

Total N in Plants (Total N Uptake)

$$
=\frac{\text { Shoot Dry Matter Weight } \times \% N \text { in Plants }}{100}
$$

$\mathrm{N}_{2}$ Fixed $=$ Total $N$ in Legume-Total $N$ in Reference Crop

$\% N d f a=\frac{\text { Total } N \text { in Legume-Total } N \text { in Reference Crop }}{\text { Total } N \text { in Legume }}$ $\times 100$

Where, Ndfa means nitrogen derived from atmosphere.

\subsubsection{Statistical analysis}

Analysis of variance (ANOVA) was done using General Linear Model (GLM) procedure of SAS 9.3 Software (SAS 2011). Means were separated using Duncan's Multiple Range Test at 5\% significance level $(P<0.05)$.

\section{Results}

\subsection{Characterization of soil and inputs}

The results obtained from chemical analysis of the experimental soil (Table 2) showed that the soil was acidic; and had moderate $\mathrm{P}$; high $\mathrm{K}$; low organic carbon and $\mathrm{N}$. The effective cation exchange capacity (ECEC) and exchangeable acidity (EA) were also low. Hence, the fertility level of the study-soil was low, however, response to $\mathrm{P}$ application alone is least expected since the soil's available P is moderate. Since the soil $\mathrm{pH}$ was acidic, lime was applied to cushion the effect of acidity and enhance better performance of the native Rhizobia inoculant used in this study. The particle size distribution (PSD) showed that the textural class of the soil was Sandy Loam according to the United State Department of
Table 2 Characteristics of the soil used in the study

\begin{tabular}{ll}
\hline Property & Soil (Field S13) \\
\hline $\mathrm{pH}$ water & 5.4 \\
Organic $\mathrm{C}\left(\mathrm{g} \mathrm{kg}^{-1}\right)$ & 1.4 \\
Available $\mathrm{P}\left(\mathrm{mg} \mathrm{kg}^{-1}\right)$ & 10.0 \\
Total P $\left(\mathrm{g} \mathrm{kg}^{-1}\right)$ & 0.3 \\
Total N $\left(\mathrm{g} \mathrm{kg}^{-1}\right)$ & 0.5 \\
Available nutrient $\left(\mathrm{g} \mathrm{kg}^{-1}\right)$ & \\
$\mathrm{K}$ & 0.5 \\
$\mathrm{Ca}$ & 0.4 \\
$\mathrm{Mg}$ & 0.1 \\
Exch. Acidity (cmol kg & \\
ECEC (cmol kg-1) & 0.4 \\
$\mathrm{C}: \mathrm{N}$ & 3.5 \\
Particle size distribution & 2.4 \\
$\quad$ Sand (\%) & \\
Silt (\%) & 54 \\
Clay (\%) & 28 \\
Textural Class & 18 \\
Cowpea's rhizobia (cfug & \\
\hline
\end{tabular}

Agriculture Research Services (SPAW 2007). The most probable number (MPN) counts of rhizobia in the soil showed native cowpea rhizobia level of $7.5 \times 10^{3} \mathrm{cfu} \mathrm{g}^{-1}$ (Table 2). Analysis of the native rhizobia inoculant for number of viable cells showed that the strain had a CFU count of $3.3 \times 10^{8}$. The quality standard which is $1.0 \times 10^{8} \mathrm{ml}^{-1}$ or g $^{-1}$ of inoculant as recommended by the National Agency for Food and Drug Administration and Control (NAFDAC) in Nigeria was used in grading the inoculants as high or low in quality. Thus, SAMFIX 286 was graded as high quality inoculant.

\subsection{Cowpea biomass and nodulation}

The only significant interaction was found between inoculants and lime, and for only nodule number (Fig. 1). Inoculation with SAMFIX 286 significantly $(p<0.05)$ improved the nodule number in the presence of lime compared to SAMFIX 286 without lime and the un-inoculated control with and without lime. This could be related to the $\mathrm{pH}$ sensitivity of the native rhizobia strain (SAMFIX 286). The native rhizobia strain was collected in northern Nigeria but not on Field S13 where the present study soil was collected. However, the inoculation of SAMFIX 286 alone or with SSP and/or lime had no significant effect on biomass and nodulation whereas, application of lime had significant $(p<0.05)$ effect on both parameters (Table 3). Application of lime significantly increased root dry weight, shoot dry weight, nodule number and dry weight by $42.5 \%, 35.3 \%, 65.6 \%$ and $50 \%$, respectively. The application of SSP significantly $(p<0.05)$ increased nodulation, i.e. nodule number and dry weight. 
Fig. 1 Interaction of Native Rhizobia Strain (SAMFIX 286) and Lime on Nodule Number (counts/plant) of Cowpea

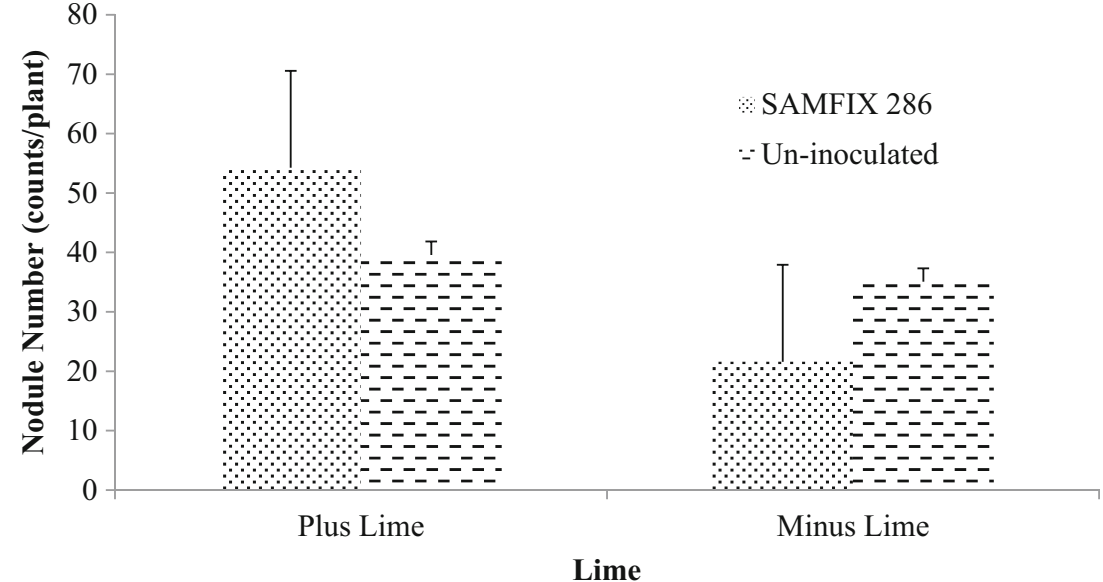

Lime

\subsection{Cowpea tissue $\mathbf{N}$ concentration and biological nitrogen fixation}

Significant interactions were observed between the inoculant and SSP as well as the combination of inoculant, lime and SSP for \% Ndfa (Figs. 2 and 3). In addition, the interactions of inoculant, lime and SSP besides lime and SSP combination significantly increased $\mathrm{N}$ concentration (Figs. 4 and 5). SAMFIX 286 with SSP significantly improved \% Ndfa, whereas in the absence of SSP, the uninoculated treatment significantly $(p<0.05)$ improved $\%$ Ndfa compared to SAMFIX 286 without SSP (Fig. 2). The combination of SAMFIX 286 with lime and SSP significantly improved \% Ndfa and $\mathrm{N}$ concentration compared to the un-inoculated treatment with lime and SSP (Figs. 3 and 4, respectively). The combined inoculation of SAMFIX 286 with lime and SSP increased N concentration by $31.9 \%$ and $\mathrm{N}$ derived from atmosphere (Ndfa) by $16.3 \%$ compared to the un-inoculated treatment. However, in the absence of lime and SSP, there were no significant differences between SAMFIX 286 and un-inoculated treatment. The interaction of inoculant and lime had no significant effect on $\mathrm{N}$ concentration, uptake and \% Ndfa (Table 4). None of the interactions had significant effect on N uptake. SAMFIX-286 and SSP had no significant effect on $\mathrm{N}$ concentration, uptake and \% Ndfa. Lime significantly decreased $\mathrm{N}$ concentration and $\%$ Ndfa.

\section{Discussion}

The experimental soil had adequate natural population of indigenous rhizobia for cowpea nodulation. Amarger
Table 3 Effects of Native Rhizobia Strain, Lime and SSP on Biomass and Nodulation of Cowpea

\begin{tabular}{lllll}
\hline Treatments & $\begin{array}{l}\text { Root Dry } \\
\text { Weight (g/plant) }\end{array}$ & $\begin{array}{l}\text { Shoot Dry } \\
\text { Weight (g/plant) }\end{array}$ & $\begin{array}{l}\text { Nodule Number } \\
\text { (counts/plant) }\end{array}$ & $\begin{array}{l}\text { Nodule Dry } \\
\text { Weight (g/plant) }\end{array}$ \\
\hline Inoculant & & & & \\
$\quad$ Un-inoculated & $1.16^{\mathrm{a}}$ & $5.98^{\mathrm{a}}$ & $37.33^{\mathrm{a}}$ & $0.07^{\mathrm{a}}$ \\
$\quad$ SAMFIX 286 & $1.45^{\mathrm{a}}$ & $6.28^{\mathrm{a}}$ & $37.92^{\mathrm{a}}$ & $0.08^{\mathrm{a}}$ \\
Lime & & & & \\
$\quad$ Plus Lime & $1.54^{\mathrm{a}}$ & $7.05^{\mathrm{a}}$ & $46.92^{\mathrm{a}}$ & $0.09^{\mathrm{a}}$ \\
$\quad$ Minus Lime & $1.08^{\mathrm{b}}$ & $5.21^{\mathrm{b}}$ & $28.33^{\mathrm{b}}$ & $0.06^{\mathrm{b}}$ \\
Phosphorus & & & & $0.12^{\mathrm{a}}$ \\
Plus SSP & $1.29^{\mathrm{a}}$ & $6.81^{\mathrm{a}}$ & $55.54^{\mathrm{a}}$ & $0.02^{\mathrm{b}}$ \\
Minus SSP & $1.33^{\mathrm{a}}$ & $5.45^{\mathrm{a}}$ & $19.71^{\mathrm{b}}$ & 0.01 \\
$\quad$ SEM & 0.13 & 0.61 & 5.09 & $\mathrm{NS}$ \\
Interactions & & & $*$ & $\mathrm{NS}$ \\
Inoculant X Lime & $\mathrm{NS}$ & $\mathrm{NS}$ & $\mathrm{NS}$ & $\mathrm{NS}$ \\
Inoculant X SSP & $\mathrm{NS}$ & $\mathrm{NS}$ & $\mathrm{NS}$ & $\mathrm{NS}$ \\
Lime X SSP & $\mathrm{NS}$ & $\mathrm{NS}$ & $\mathrm{NS}$ & $\mathrm{NS}$ \\
Inoculant X Lime X SSP & $\mathrm{NS}$ & $\mathrm{NS}$ & & \\
\hline
\end{tabular}

Means with the same letter within a treatment are not significantly different $(p<0.05)$ using DMRT (Duncan Multiple Range Test)

*Significant at $p<0.05$ and NS Not Significant at $p<0.05$ 
Fig. 2 Interaction Effects of Native Rhizobia Strain and SSP on Percent (\%) N Derived from Atmosphere

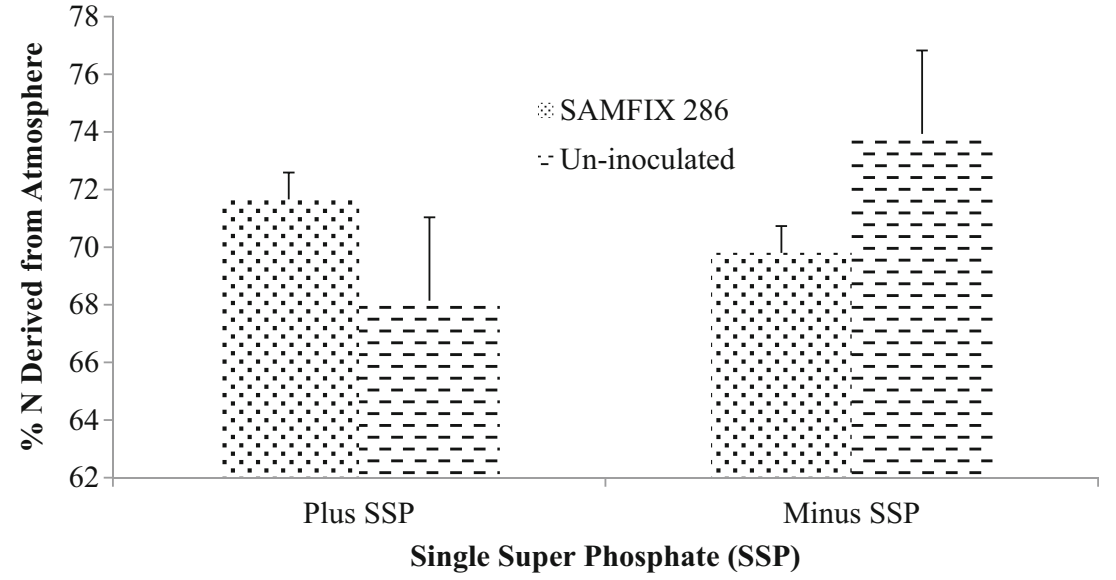

Vinuesa et al. 2003). In addition to the high population of indigenous rhizobia population, the study soil had low levels of organic matter, total $\mathrm{N}$ and it was acidic (Brockwell et al. 1991), which could have affected the symbiotic performance of the introduced rhizobia strain when used without lime and SSP.

The variable response to the co-application of inoculants and lime could be explained by the low application rate, which calls for the reassessment of lime recommendations in Nigeria. For example, in the soil acidity amelioration study of Peoples et al. (1995), lime was applied at the rate of $2500 \mathrm{~kg} \mathrm{ha}^{-1}$ and this only raised the soil $\mathrm{pH}$ from 4.5 to 4.9 . The increase in nodule number and dry weight of cowpea due to the application of lime was in concordance with the study of Bekere et al. (2013) where it was reported that lime application significantly increased number of nodules. Calcium supplied to plants through lime is essential component in symbiotic $\mathrm{N}_{2}$-fixation and nodule formation in legumes (Bambara and
Fig. 3 Interaction Effects of Native Rhizobia Strain, Lime and SSP on Percent (\%) N Derived from Atmosphere

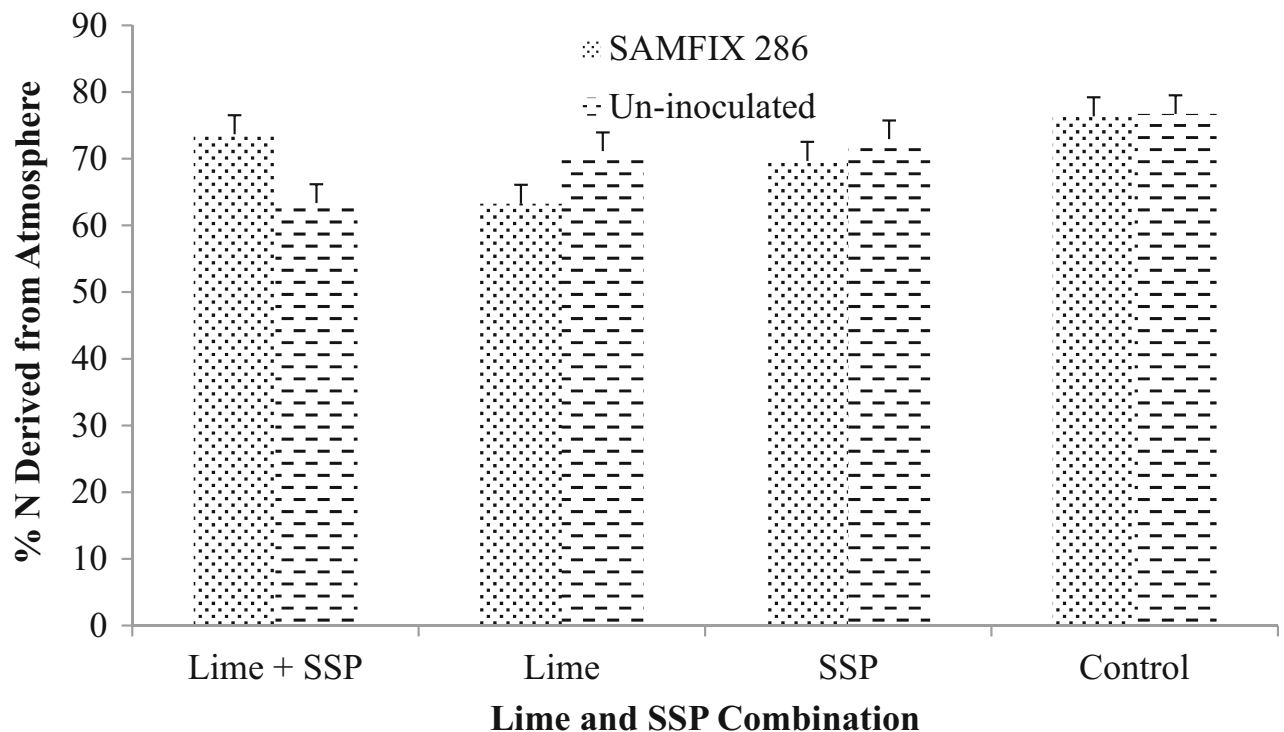

Lime and SSP Combination 
Fig. 4 Interaction Effects of Native Rhizobia Strain, Lime and SSP on Shoot N Concentration of Cowpea

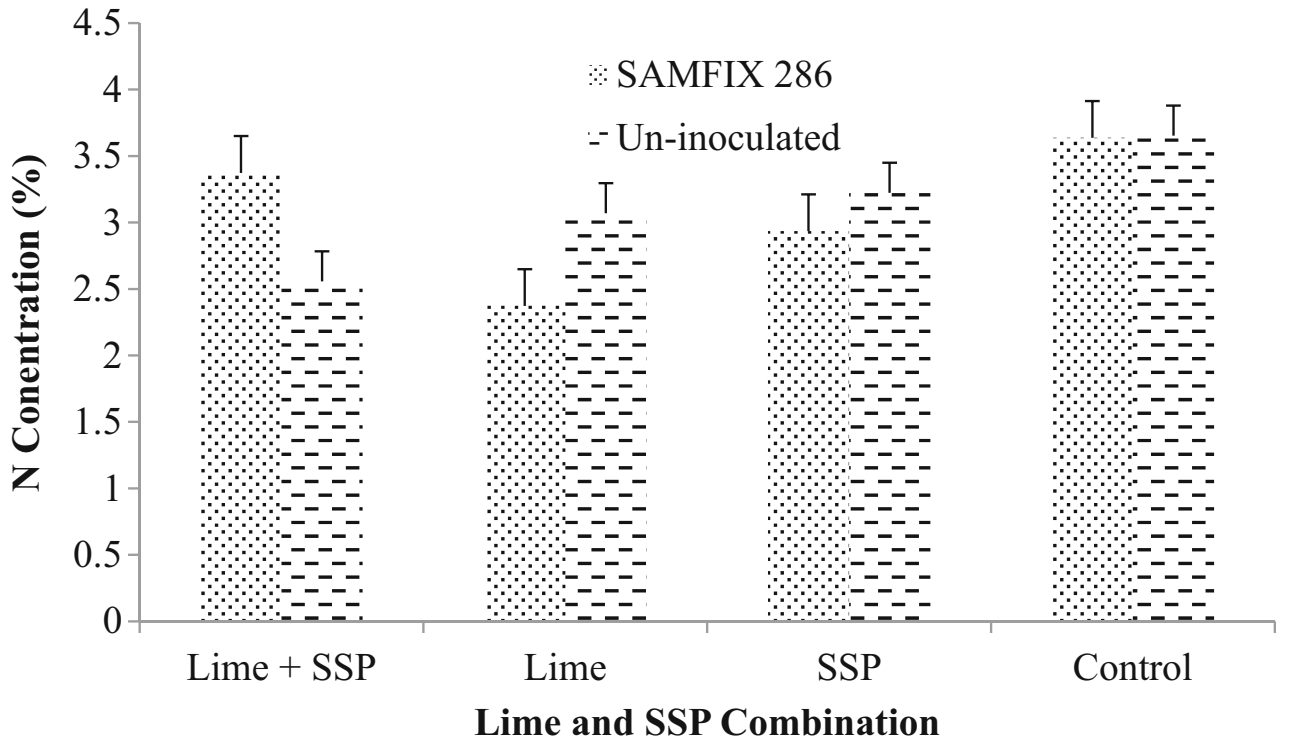

Ndakidemi 2010). The application of lime using $\mathrm{Ca}(\mathrm{OH})_{2}$ to bind excess $\mathrm{H}^{+}$or $\mathrm{Al}^{3+}$ responsible for low soil $\mathrm{pH}$ while at the same time releasing $\mathrm{Ca}^{2+}$ as a nutrient could be said to have significant impact on cowpea growth in this study. The effectiveness of lime was further exhibited in nodule numbers when SAMFIX 286 was co-applied with it. The major influence of lime when applied in the soil is its ability to supply $\mathrm{Ca}^{2+}$ which is essential for plant growth (White and Broadley 2003) and neutralizing the toxicity effects of $\mathrm{H}^{+}, \mathrm{Al}^{3+}$ and $\mathrm{Mn}^{2+}$ in the soil (Staley and Brauer 2006). Consequently, lime also improved root and shoot dry weight. In the present study, there was no response to SSP application, in terms of root and shoot dry weight, due to the moderate level of $\mathrm{P}$ in the soil. This finding was in contrary to the study of Akande et al. (2010) who reported that application of $\mathrm{SSP}$ at the rate of $60 \mathrm{~kg} \mathrm{P} / \mathrm{ha}$ significantly increased the shoot dry weight of cowpea due to the low level of $\mathrm{P}$ in the study soil. However, $\mathrm{P}$ application synergistically worked with SAMFIX 286 to improve \% Ndfa by cowpea. The quantity of $\mathrm{P}$ was sufficient to support nodule growth and activity; and the $\mathrm{pH}$ was above the critical limit of 5.0 for BNF (Howieson and Ballard 2004). Bhuiyan et al. (2008) reported that, the application of $\mathrm{P}$ along with rhizobia inoculant influences $\mathrm{N}_{2}$ fixation of legume crops. Phosphorus provides the mechanism for energy storage in the form of ATP and the transfer of that energy source to fuel vital plant functions such as $\mathrm{N}_{2}$ fixation (IPNI 1999). Nodulation, $\mathrm{N}_{2}$ fixation, and specific nodule activity are directly associated to $\mathrm{P}$ contribution (Abdulameer 2011).

The combined application of lime and SSP with SAMFIX 286 is an appropriate combination for improving $\mathrm{N}$ accumulation and $\mathrm{N}_{2}$ fixation by cowpea. The
Fig. 5 Interaction Effects of Single Super Phosphate and Lime on Shoot N Concentration of Cowpea

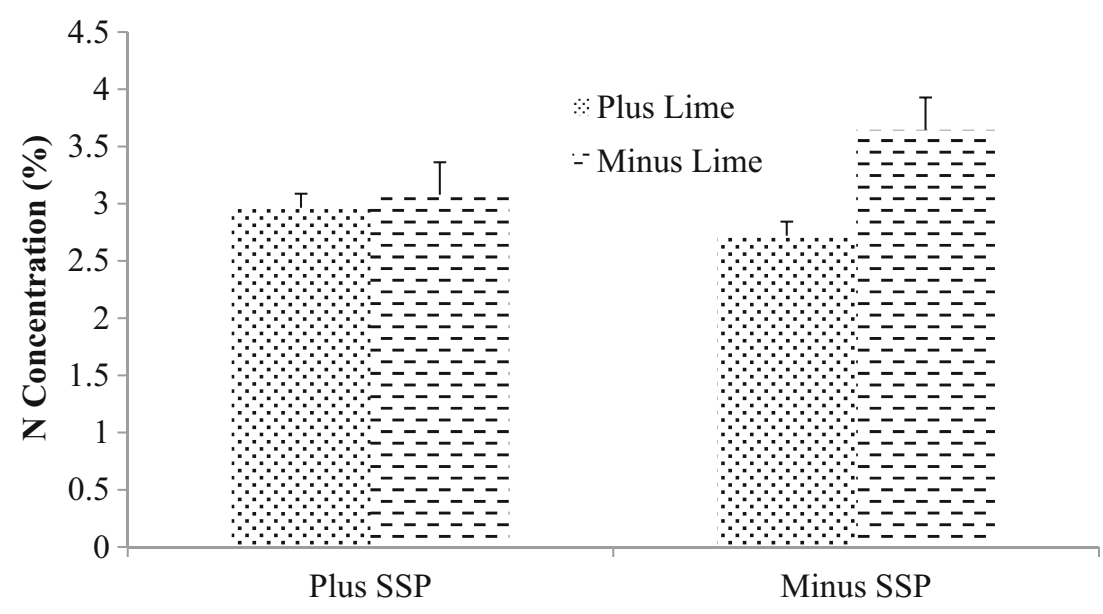

Single Super Phosphate 
Table 4 Effects of Native Rhizobia Strain, Lime and SSP on N Concentration, Uptake and Percentage N Derived from Atmosphere in Cowpea

\begin{tabular}{llll}
\hline Treatments & $\begin{array}{l}\text { N Concentration } \\
(\%)\end{array}$ & $\begin{array}{l}\text { N Uptake } \\
(\mathrm{mg} / \mathrm{plant})\end{array}$ & $\%$ Ndfa \\
\hline Inoculant & & & \\
$\quad$ Un-inoculated & $3.13^{\mathrm{a}}$ & $183.68^{\mathrm{a}}$ & $71.03^{\mathrm{a}}$ \\
$\quad$ SAMFIX 286 & $3.08^{\mathrm{a}}$ & $183.06^{\mathrm{a}}$ & $70.73^{\mathrm{a}}$ \\
Lime & & & \\
$\quad$ Plus Lime & $2.84^{\mathrm{b}}$ & $198.68^{\mathrm{a}}$ & $67.85^{\mathrm{b}}$ \\
$\quad$ Minus Lime & $3.36^{\mathrm{a}}$ & $168.06^{\mathrm{a}}$ & $73.92^{\mathrm{a}}$ \\
Phosphorus & & & \\
$\quad$ Plus SSP & $3.02^{\mathrm{a}}$ & $200.66^{\mathrm{a}}$ & $71.87^{\mathrm{a}}$ \\
$\quad$ Minus SSP & $3.18^{\mathrm{a}}$ & $166.08^{\mathrm{a}}$ & $69.90^{\mathrm{a}}$ \\
$\quad$ SEM & 0.13 & 17.31 & 1.35 \\
Interactions & & & \\
Inoculant x Lime & $\mathrm{NS}$ & $\mathrm{NS}$ & $\mathrm{NS}$ \\
Inoculant X SSP & $\mathrm{NS}$ & $\mathrm{NS}$ & $*$ \\
Lime x SSP & $*$ & $\mathrm{NS}$ & $\mathrm{NS}$ \\
Inoculant X Lime X SSP & $*$ & $\mathrm{NS}$ & $*$ \\
\hline
\end{tabular}

Means with the same letter(s) within a treatment are not significantly different $(p<0.05)$ using DMRT (Duncan Multiple Range Test).

*Significant at $p<0.05$ and NS Not Significant at $p<0.05$. \% Ndfa N derived from atmosphere

fundamental practice of liming acid soils is significant to the relationship between $\mathrm{P}$ and the symbiotic $\mathrm{N}$ fixation process (IPNI 1999). It improves the availability of soil $\mathrm{P}$ for plant absorption and creates a soil environment more favourable for beneficial bacteria such as the different strains of Rhizobium. Nodules develop when a root hair is infected by Rhizobium bacteria. Plant tissue develops around the infected area, forming the nodule and site of bacterial growth and the fixation of elemental $\mathrm{N}$ from the soil atmosphere (IPNI 1999).

\section{Conclusion}

The effectiveness of lime and SSP varied in their performance on cowpea growth. Lime was effective on cowpea growth and could be recommended for cowpea cultivation on acidic soil to counter the negative effects of soil acidity; however, the appropriate rate requires further investigation. The application of SSP also positively influenced cowpea growth. The inoculant strain (SAMFIX 286) was less tolerant to low P conditions compared to other indigenous strains and thus, did not improve plant growth. Importantly, over the single effect of the treatments, the synergistic relationship between the treatments was found to be very important in improving the growth and yield of cowpea. It was concluded that lime and SSP were good combination with the native Rhizobia strain in improving cowpea nodulation and $\mathrm{N}_{2}$ fixation. Importantly, this study was limited to greenhouse evaluation and will require validation under field conditions at large scale before general recommendations could be made.

Acknowledgements The authors would like to acknowledge the services of the staff of Soil Microbiology Unit, Department of Soil Science, Ahmadu Bello University, Zaria, Kaduna State, Nigeria. The authors are also very thankful to the International Institute of Tropical Agriculture (IITA) for the financial support of the research through the COMPRO II Project funded by Bill and Melinda Gate Foundation.

Open Access This article is distributed under the terms of the Creative Commons Attribution 4.0 International License (http:// creativecommons.org/licenses/by/4.0/), which permits unrestricted use, distribution, and reproduction in any medium, provided you give appropriate credit to the original author(s) and the source, provide a link to the Creative Commons license, and indicate if changes were made.

\section{References}

AATF, African Agricultural Technology Foundation (2012) Potentials and constraints: cowpea for food and poverty alleviation. Policy Brief: The Maruca-Resistant Cowpea Project. https://www.aatfafrica.org/files/files/publications/Cowpea\%20brief.pdf. Accessed 21 Aug 2017

Abaidoo RC, Keyser HH, Singleton PW, Dashiell KE, Sanginga N (2007) Population size, distribution and symbiotic characteristics of indigenous Bradyrhizobium sp. that nodulate TGx soybean genotypes in Africa. Appl Soil Ecol 35:57-67

Abdulameer AS (2011) Impact of rhizobial strains mixture, phosphorus and zinc applications in nodulation and yield of bean (Phaseolus vulgaris L.) Baghdad Sci J 8(1):357-365

Akande MO, Makinde EA, Oluwatoyinbo FI, Adetunji MT (2010) Effects of phosphate rock application on dry matter yield and phosphorus recovery of maize and cowpea grown in sequence. Afr J Environ Sci Technol 4(5): 293-303. http://www.Academicjournals.Org/AJEST accessed on 21 Aug 2017

Amarger N (2001) Rhizobia in the field. Adv Agron 73:109-168

Anderson JM, Ingram JSL (1993). Tropical soil biology and fertility (TSBF): a handbook of methods, $2^{\text {nd }}$ edn. CAB International, UK, p 221

Balume KMI (2013) Assessment of quality control of inoculants used on bean and soybean in eastern and central Africa. Master's thesis, University of Nairobi, Nairobi

Bambara S, Ndakidemi AP (2010) The potential roles of lime and molybdenum on the growth, nitrogen fixation and assimilation of metabolites in nodulated legume: a special reference to Phaseolus vulgaris L. Afr J Biotechnol 8(17):2482-2489

Bekere W, Kebede T, Dawud J (2013) Growth and nodulation of soybean (Glycine max L.) to lime, Bradyrhizobium japonicum and nitrogen fertilizer in acid soil at Melko, south West Ethiopia. Int J Soil Sci $8(1): 25-31$

Bhuiyan MMH, Rahman MM, Afroze F, Sutradhar GNC, Bhuiyan MSI (2008) Effect of phosphorus, molybdenum and rhizobium inoculation on growth and nodulation of mungbean. J Soil Nature 2(2):25-30

Blackshaw RE, Brandt RN (2009) Phosphorus fertilizer effects on the competition between wheat and several weed species. Weed Biol Manag 9:46-53

Bray RH, Kurtz LT (1945) Determination of total, organic, and available forms of phosphorus in soils. Soil Sci 59:39-45 
Bremner JM, Mulvaney CS (1982) Nitrogen -total. In: Page AL, Miller, RH, Keeney DR (eds), Methods of soil analysis, part 2. American Society of Agronomy 9:595-624

Brockwell J, Pilka A, Holliday R (1991) Soil pH is a major determinant of the numbers of naturally occurring Rhizobium meliloti in noncultivated soils in central New South Wales. Aust J Exp Agric 31: 211-219. https://doi.org/10.1071/EA9910211

Chand S, Anwar M, Patra DD (2006) Influence of long-term application of organic and inorganic fertilizer to build up soil fertility and nutrient uptake in mint-mustard cropping sequence. Commun Soil Sci Plant Anal 37:63-76

Chianu JN, Nkonya EM, Mairura FS, Chianu JN, Akinnifesi FK (2011) Biological nitrogen fixation and socioeconomic factors for legume production in sub-saharan Africa: a review. Agron Sustain Dev 31: 139-154. https://doi.org/10.1051/agro/2010004

Gee GW, Bauder JW (1986) Particle-size analysis. Methods of soil analysis. Part physical and mineralogical methods, $2^{\text {nd }}$ edn. American society of agronomy, Madison, pp 383-411

Giller KE, Cadisch G, Ehaliotis C, Adams E, Sakala WD, Mafongonya PL (1997) Building soil nitrogen capital in Africa. In: Buresh RJ, Sanchez PA, Calhoun F (eds) replenishing soil fertility in Africa. Madison: SSSA special publication number 51. SSSA and ASA, pp. 151-192

Ham GE, Caldwell VB, Johnson HW (1971) Evaluation of Bradyrhizobium Japonicum in soils containing naturalized populations of rhizobia. Agron J 63:301-303

Howieson J, Ballard R (2004) Optimizing the legume symbiosis in stressful and competitive environments within southern Australia - some contemporary thoughts. Soil Biol Biochem 36:1261-1273

IITA, International Institute of Tropical Agriculture, (1982) Automated and semi- automated methods of soil and plant analysis. IITA manual series 7: 33

IPNI, International Plant Nutrition Institute (1999) Effects of Phosphorus on Nitrogen Fixation. Better Crops 83(1): 30-31. http://www.ipni. $\mathrm{n} \mathrm{e} \mathrm{t/p} \mathrm{u} \mathrm{b} 1$ i c a t i o n / b e t t e r c r o p s. n s f/ $0 /$ C480DBBAC5FE3E0A852579800082018C/\$FILE/Better\% 20Crops\%201999-1\%20p30.pdf. Accessed 21 Aug 2017

ISRIC, International Soil Reference Information Center (1995) In: Reeuwijik LPV (ed) Technical paper 9: procedure for soil analysis, 5 th edn. Wageningen, ISRIC

Jansa A, Bationo A, Frossard E, Rao IM (2011) Options for improving plant nutrition to increase common bean productivity in Africa. In: Bationo AW (ed) Fighting poverty in subSaharan Africa: the multiple roles of legumes in integrated soil fertility management. Springer Science, Business Media, pp 201-240

Mapfumo P (2011) Comparative analysis of the current and potential role of legumes in integrated soil fertility management in southern Africa. In: Bationo AW (ed) Fighting poverty in subSaharan Africa: the multiple roles of legumes in integrated soil fertility management. Springer Science, Business Media, pp $175-200$

Marenya PP, Barrett CB (2007) Household-level determinants of improved natural resource management practices among smallholder farmers in western Kenya. Food Policy 32:515-536

Mary SV, Carlos MS, Segundo U, Robert MB (1995) Quantification of the contribution of $\mathrm{N}_{2}$ fixation to tropical forage legumes and transfer to association grass. Soil Biol Biochem 27:1193-1200

Miko S, Mohammed IB (2007) Performance of improved cowpea genotypes in the Sudan savanna: I. Growth and dry matter production. Biological and Environmental Sciences Journal for the Tropics 4(1):12-18

Minot N, Benson T (2009) Fertilizer subsidies in Africa: are vouchers the answer? IFPRI (international food policy research Insitute) issue brief: 60. IFPRI, Washington, D.C.

Moreira FMS (2008) Nitrogen fixing bacteria nodulating legumes. In: Moreira FMS, Siqueira JO, Brussaard L (eds) Soil biodiversity in Brazilian ecosystems. UFLA, Lavras, pp 621-680
Mungai NW, Karubiu NM (2011) Effectiveness of rhizobia isolates from Njoro soils (Kenya) and commercial inoculants in nodulation of common beans (Phaseolus Vulgaris). J Agric Sci Technol 12(1):47-59

Murphy J, Riley J (1962) A modified single solution method for the determination of phosphate in natural waters. Anal Chem Acta 27: 31-36. https://doi.org/10.1016/S0003-2670(00)88444-5

Mwangi TJK (1994) Effects of Bradyrhizobium inoculation and nitrogen fertilization on growth, nodulation and yield of soybeans. M.Sc. Thesis, University of Nairobi, Kenya

Nandwa SM (2003) Soil organic carbon (SOC) management for sustainable productivity of cropping and agroforestry systems in eastern and southern Africa. Nutr Cycl Agroecosyst 61:143-158

Nelson DW, Sommers LM (1982) Total carbon, organic carbon and organic matter. In: Page AL (ed) Methods of soil analysis, part 2, Monogram, vol 9, 2nd edn. ASA and SSSA, Madison, pp 539-577

Nicolás MF, Hungria M, Arias CAA (2006) Identification of quantitative trait loci controlling nodulation and shoot mass in progenies from two Brazilian soybean cultivars. Field Crops Res 95:355-366

Peoples MB, Ladha JK, Herridge DF (1995) Enhancing legume $\mathrm{N}_{2}$ fixation through plant and soil management. Plant Soil 174:83-101

Raven JA (2012) Protein turnover and plant RNA and phosphorus requirements in relation to nitrogen fixation. Plant Sci 188-189:25-35

Sanchez PA, Shepherd JD, Soule MJ, Place FM, Buresh RJ, Izac AMN, Mokwunye AU, Kwesiga FR, Ndiritu CG, Woomer PL (1997) Soils fertility replenishment in Africa: an investment in natural resource capital. In: Buresh RJ, Sanchez PA, Calhoun F (eds) Replenishing soil fertility in Africa, soil science Society of America Special Publication 51. SSSA and ASA, Madison, pp 1-46

Sanginga N, Woomer PL (2010) Integrated soil fertility management in Africa: principles, practices and developmental process (p. 13). Tropical soil biology and fertility Institute of the International Centre for tropical agriculture (TSBF-CIAT), Nairobi, pp 263

Sanginga N, Mulongoy K, Ojeifo AA (1994) Persistence and recovery of induced rhizobium ten years after inoculation on leucaena leucocephala grown on an Alfisol in southwestern Nigeria. Plant Soil 159:199-204

SAS Software version 9.3 (2011) Statistical analysis system. Institute Incorporation, Cary

Schulze J, Temple GA, Temple SJ, Beschow H, Vance CP (2006) Nitrogen fixation by white lupin under phosphorus deficiency. Ann Bot 98:731-740

Shamseldin A (2007) Use of DNA marker to select well-adapted Phaseolus-symbionts strains under acid conditions and high temperature. Biotechnol Lett 29:37-44

Shamseldin A, Werner D (2004) Selection of competitive strains of Rhizobium nodulating Phaseolus vulgaris and adapted to environmental conditions in Egypt, using the gus-reporter gene technique. World J Microbiol Biotechnol 20:377-382

Somasegaran P, Hoben HJ (1985) Methods in legume-rhizobium technology. NifTAL and MIRCEN, Maui

SPAW, Soil-Plant-Air-Water Computer Model (2007) Soil water characteristics: hydraulic 457 properties calculator. United State Department of Agriculture (USDA) Agricultural 458 Research Services. http://www.bsyse.wsu.edu/saxton

Staley TE, Brauer DK (2006) Survival of a genetically modified rootcolonizing pseudomonad and rhizobium strain in an acidic soil. Soil Sci Soc Am J 70:1906-1913

Tarawali SA, Singh BB, Gupta SC (2002) Cowpea as a key factor for a new approach to integrate crop-livestock systems research in dry savannas of West Africa. In: challenges and opportunities for enhancing sustainable cowpea production. Proceedings of the world cowpea conference III held at the International Institute of Tropical Agriculture (IITA), Ibadan, Nigeria

Vanlauwe BJ, Diels K, Aihou I, Iwuafor INO, Lyasse O, Sanginga N, Merckx R (2002) Direct interactions between N fertiliser and 
organic matter: evidence from trials with 15 Nlabelled fertiliser. In: Vanlauwe B, Diels N, Sanginga N, Merkx R (eds) Integrated nutrient Management in sub-Saharan Africa: from concept to practice. CAB International, Wallingford, pp 173-184

Vanlauwe B, Bationo A, Giller KE et al (2010) Integrated soil fertility management. Operational definition and consequences for implementation and dissemination. Outlook on Agriculture 39(1):17-24

Vinuesa P, Neumann-Silkow F, Pacios-Bras C, Spaink HP, MartinezRomero E, Werner D (2003) Genetic analysis of a pH-regulated operon from Rhizobium tropici CIAT899 involved in acid tolerance and nodulation competitiveness. Mol Plant Microbe Interact 16:159-168

White PJ, Broadley MR (2003) Calcium in plants. Ann Bot 92:487-511

Woomer PL, Singleton PW, Bohlool BB (1988) Reliability of most probable number technique for enumerating rhizobia in tropical soils. Appl Environ Microbiol 54:1494-1497

Woomer PL, Martin A, Albrecht A, Resck DVS, Scharpenseel HW (1994) The importance and management of soil organic matter in the tropics. In: Woomer PL, Swift MJ (eds) The biological Management of Tropical Soil Fertility. Wiley, Chichester, pp 47-80

Woomer PL, Nancy K, Stanley MK (2010) Advancing technical skills in rhizobiology. A two week training course conducted in the east and Central Africa hub of the $\mathrm{N}_{2}$ Africa project, pp 2-22

Yusuf AA, Iwuafor ENO, Olufajo OO, Abaidoo RC, Sanginga N (2007) Genotype effects of cowpea and soybean on nodulation, $\mathrm{N}_{2}$-fixation and $\mathrm{N}$ balance in the northern Guinea savanna of Nigeria. In: Proceeding of the $31^{\text {st }}$ annual conference of the soil science Society of Nigeria. Ahmadu Bello University, Zaria, pp $147-154$

Zerihun A, Sharma JJ, Nigussie D, Fred K (2013) The effect of integrated organic and inorganic fertilizer rates on performances of soybean and maize component crops of a soybean/maize mixture at Bako, western Ethiopia. Afr J Agric Res 8(29):3921-3929. https://doi.org/ 10.5897/AJAR12.1044 